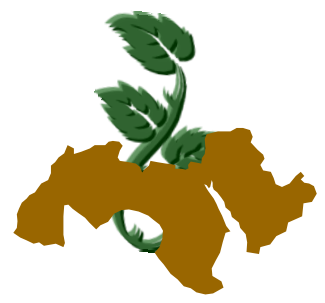

Arab Univ. J. Agric. Sci., Ain Shams Univ., Cairo, 16(2), 309-317, 2008

\title{
RESPONSE OF FABA BEAN (VICIA FABA L.) TO COMBINED INOCULATION WITH RHIZOBIA, VA-MYCORRHIZAE AND PHOSPHATE SOLUBILIZING BACTERIA UNDER SANDY SOIL CONDITIONS
}

\author{
Saleh$^{1}$, S.A.; M.A. Nassef ${ }^{2}$; F.T. Mikhaeel ${ }^{2}$ and A.A. Abou El-Soud ${ }^{2}$ \\ 1- National Gene Bank and Genetic Resources, ARC, Giza, Egypt \\ 2- Soils, Water and Environ. Res. Instit., ARC, Giza, Egypt
}

Keywords: Faba bean, (Viceae faba L.), Rhizobium leguminosarum bv. viceae, Bacillus megaterium var. phosphaticum, VA- mycorrhizal fungus, Phosphorus-deficient, sandy soils

\section{ABSTRACT}

A pot experiment was conducted at controlled greenhouse of Bio-fertilizers production Unit; Soils, Water and Environment Research Institute, ARC, Giza through the winter growing season of $2006 / 2007$ to evaluate the effects of symbiotic nitrogen fixing bacteria (Rhizobium leguminosarum bv. viceae), phosphate solubilizing bacteria (Bacillus megaterium var. phosphaticum) and VAM fungus (Glomus sp.) on nodulation, $\mathrm{N}_{2}$-fixation, growth, $\mathrm{N}$ and $\mathrm{P}$ uptake of faba bean plants grown in phosphorus-deficient sandy soils. The obtained data resulted in significant increases in VA- Mycorrhizal colonization ratios when soil inoculated with rhizobia and VA-Mycorrhizae as compared with the other treatments. In addition, rock-P fertilized plants exhibited significant increases in VAM colonization ratios when compared with those supplemented with super-P. Concerning of dual inoculation with Rhizobium and Bacillus, the results indicated higher increases in VA- mycorrhizae colonization ratios as compared with the uninoculated or inoculated treatments with rhizobia alone, being most pronounced in the rock-P amended soil. The obtained results showed clearly that combined inoculation of faba bean with rhizobia and VAMycorrhizae in a soil amended with rock-P or super- $P$, gave the highest significant increases in nodulation, nitrogen fixation, plant biomass, $\mathrm{N}$ and $P$ uptake when compared with the plants inoculated with Rhizobium alone. On the other hand, combined inoculation with Rhizobium and Bacillus megaterium did not record significant influence on the abovementioned parameters as compared to inoculation with Rhizobium alone.

\section{INTRODUCTION}

Significant areas of cultivated sandy soils in Egypt are deficient of available N, P and K. In modern agriculture, the replenishment of soil nitrogen involves most commonly extensive application of chemical fertilizers (Peoples et al 1995), an approach which has several serious drawbacks, high cost and severe negative environmental impacts. These considerations stimulated research on other alternatives, such as biological nitrogen fixation which contributes more than 170 million tons of fixed nitrogen to the biosphere. Eighty percent of the stable biologically fixed nitrogen is a direct result of the rhizobiaceae and some actinomycetes symbioses with leguminous and certain non-leguminous plants, respectively (Earl and Ausubel, 1993).

The dual inoculation with both rhizobia and VA mycorrhizae induced more significant increases in plant dry weight, $\mathrm{N}$ and $\mathrm{P}$ content of lentil and faba bean as well as seed yield of soybean than inoculation with either VA mycorrhizae or Rhizobium alone (Badr El-Din and Moawad, 1988).

The use of plant growth promoting rhizobacteria (PGPR), including phosphate solubilizing bacteria as biofertilizers was suggested as a sustainable solution to improve plant nutrient and production (Vessey, 2003). Direct application of rock phosphate may be agronomically more useful and environmentally more feasible than soluble P (Rajan et al 1996).

Phosphorus is one of the major nutrients limiting plant growth. Most soils throughout the world 
are $P$ deficient (Batjes, 1997) and therefore require $P$ to replenish the $P$ demand by crop plants. To circumvent the $P$ deficiency in soils, $P$ fertilizers could be applied. However, after application, a considerable amount of $P$ is rapidly transformed into less available forms by forming a complex with $\mathrm{Al}$ or Fe in acid soils (Norrish and Rosser, 1983) or Ca in calcareous soils (Lindsay et al 1989) before plant roots have a chance to absorb it. Further, the use of rock phosphate as a phosphate fertilizer and its solubilization by microbes (Kang et al 2002), through the production of organic acids (Maliha et al 2004), have become a valid alternative to chemical fertilizers. Rock phosphate is widely distributed throughout the world, both geographically and geologically (Zapata and Roy, 2004). In conjugation with phosphate solubilizing microorganisms (PSM), rock phosphate provides a cheaper source of $P$ fertilizer for crop production, however most of them are not readily available to a plant. In this regard, several studies showed that PSM solubilizes the fixed soil $P$ and applied phosphates, resulting in higher crop yields (Zaidi, 1999 and Gull et al 2004). The alternative approach is to use these PSM along with other beneficial rhizospheric microflora to enhance crop productivity. In this context, the simultaneous application of Rhizobium and PS microorganisms (Perveen et al 2002) and arbuscular mycorrhizal VAM fungi (Zaidi et al 2003) has been shown to stimulate plant growth more than inoculation of each microorganism alone in certain situations when the soil is $P$ deficient. On the other hand, VAM fungi encourage the plant roots to absorb rapidly the solubilized $P$. Accordingly, the increase in plant growth may be due to the release of certain plant growth promoting substances (Kucey et al 1989) by the PS organisms or VAM development and mycorrhizal formation (Azcon-Aguilar and Barea, 1985). However, the inoculation effect of the tripartite interaction between $\mathrm{N}_{2}$ - fixing bacteria, PSM and VAM fungus on legume crops are relatively scarce (Zaidi et al 2004).

Because the minerals are released slowly and their use as fertilizers often causes insignificant yield increases of current crop (Zapata and Roy, 2004). Phosphate solubilizing bacteria (PSB) have been used to improve rock $P$ value because they convert insoluble rock $P$ into soluble forms available for plant growth (Bojinova et al 1997). This conversion is through acidification, chelation and exchange reactions (Gerke, 1992) and produces strong organic acids, which have become indicators for routine isolation and selection procedures of PSB (IIImer et al 1995). Bacillus megaterium var. phosphaticum is known for its ability to solubilize rock $P$ material (Schilling et al 1998).

The aim of the present study was to evaluate the response of faba bean to Rhizobium inoculation combined with VA-mycorrhizae and phosphate solublizing bacteria under sandy soil conditions.

\section{MATERIALS AND METHODS}

\section{Microbial cultures}

Rhizobium leguminosarum bv. viceae, strain ICARDA 441; Bacillus megaterium var. phosphaticum (local isolate) and VA- mycorrhizal fungus (local isolate of Glomus spp.) were supplied by Biofertilizer Production Unit; Soils, Water and Environment Research Institute; ARC; Giza; Egypt.

\section{Preparation of microbial inoculants}

Rhizobium strain was grown on yeast extract mannitol broth medium (Vincent, 1970) at $28^{\circ} \mathrm{C}$ under shaking at $250 \mathrm{rpm}$ for 3 days until early log phase $\left(5 \times 10^{9} \mathrm{cfu} / \mathrm{ml}\right.$ culture). Vermiculite mixed with $10 \%$ peat was packed in polyethylene bags (180 $\mathrm{g}$ carrier per bag), then sealed and sterilized by gamma irradiation ( $5.0 \times 10^{6}$ rads). Rhizobium culture was injected into the carrier to satisfy $60 \%$ of the maximal water holding capacity.

Bacillus megaterium was grown on nutrient broth medium under shaking at $250 \mathrm{rpm}$ for $48 \mathrm{hrs}$ at $28^{\circ} \mathrm{C}$. Viable bacterial cells $\left(4 \times 10^{8} \mathrm{cfu} / \mathrm{ml}\right.$ culture) was injected in the abovementioned carrier materials used in Rhizobium inoculants.

Viscular Arbuscular mycorrhizal (VAM) fungi spores were propagated for 16 weeks on Sorghum bicolor in sterilized pot cultures prior to the start of the experiment. Soil from 16 week-old pot culture was used as a crude inoculum consisted of soil, mycorrhizal spores and infected roots.

\section{Pot experiment}

Pot experiment was conducted at the controlled greenhouse of Biological Nitrogen Fixation Unit; Soils, Water and Environment Research Institute, Agricultural Research Center, Giza through the winter growing season of 2006/2007 to study the Effect of Rhizobium inoculation combined with VMmycorrhizae and phosphate dissolving bacteria on growth, nodulation, nitrogen fixation and phosphorus uptake in faba bean plants under sandy soils. 
The soil used in pot experiment was collected from Ismailia Research Station. The main physicochemical characteristics of the soil were determined according to Jackson (1973) and Page et al (1982), (Table 1).

Table 1. Some physical and chemical properties of the used soil

\begin{tabular}{|lc|lc|}
\hline \multicolumn{2}{|c|}{ Physical properties } & \multicolumn{2}{|c|}{ Chemical properties } \\
\hline Sand & $90.20 \%$ & $\mathrm{pH}$ & 7.30 \\
Silt & $5.68 \%$ & $\mathrm{E} . \mathrm{C} .\left(\mathrm{dS} \mathrm{m}^{-1}\right)$ & 0.35 \\
Clay & $4.12 \%$ & Soluble cations (meq l-1) & \\
Textural class & Sandy & $\mathrm{Ca}^{++}$ & 0.57 \\
$\mathrm{CaCO}_{3}$ & $0.57 \%$ & $\mathrm{Mg}^{++}$ & 0.48 \\
$\mathrm{SP}$ & $19.65 \%$ & $\mathrm{Na}^{+}$ & 1.27 \\
& & $\mathrm{~K}^{+}$ & 1.10 \\
& & $\mathrm{Soluble}^{-}$anions (meq l-1) & \\
& $\mathrm{CO}_{3}^{--}$ & 0.00 \\
& & $\mathrm{HCO}_{3}^{-}$ & 1.09 \\
& $\mathrm{Cl}^{-}$ & 0.76 \\
& & $\mathrm{SO}_{4}^{--}$ & 1.58 \\
& & Total Solble N ppm & 25.3 \\
& & Available P ppm & 8.2 \\
\hline
\end{tabular}

Plastic pots (30 cm diameter) were filled with $10 \mathrm{~kg}$ of the soil. All pots received the recommended dose of potassium sulphate $\left(48.5 \% \mathrm{~K}_{2} \mathrm{O}\right)$ at the rate of $100 \mathrm{~kg} \mathrm{fed}^{-1}$ applied at two equal doses (10 and 20 days of planting). The pots were divided into two main plots. The first main group was fertilized with super-phosphate $\left(15.5 \% \mathrm{P}_{2} \mathrm{O}_{5}\right)$ at a rate of $200 \mathrm{~kg}$ fertilizer/fed. The second group was fertilized with rock phosphate $\left(27 \% \mathrm{P}_{2} \mathrm{O}_{5}\right)$ at a rate of $115 \mathrm{~kg}$ fertilizer/fed. All treatments received ammonium sulphate $(20.5 \% \mathrm{~N})$ at a rate of $20 \mathrm{~kg} \mathrm{~N}$ $\mathrm{fed}^{-1}$ as a starter dose of nitrogen. The nitrogen control treatment fertilized with $40 \mathrm{~kg} \mathrm{~N}$ fed $^{-1}$. The $\mathrm{N}$-fertilizer applied at two equal doses (10 and 20 days of planting). Pots were arranged in a complete randomized design with four replicates.

Faba bean seeds variety Giza 40 were supplied from Food Legume Research Department, Field Crops Research Institute, ARC and inoculated with vermiculite-based inoculants containing Rhizobium or Bacillus megaterium. Each inoculant was applied at the rate of two bags per seeds of feddan using $16 \%$ Arabic gum solution as a sticking agent.

Mycorrhizal inoculation of experimental pots were achieved by placing $75 \mathrm{~g}$ of the crude inoculum, $2-4 \mathrm{~cm}$ below the soil surface before planting. The used inoculum contained approximately 25 viable propagules per gram of mycorrhizal inoculum, which were estimated using the Most Probable Number (MPN) technique (Daniels and Skipper, 1982).

The following treatments were applied:

1- Uninoculated + superphosphate

2- Uninoculated (N-control) + superphosphate

3- Rhizobium + superphosphate

4- Rhizobium + Mycorrhizae + superphosphate

5- Rhizobium + Bacillus megaterium + superphosphate

6- Uninoculated + rock phosphate

7- Uninoculated (N-control) + rock phosphate

8- Rhizobium + rock phosphate

9- Rhizobium + Mycorrhizae + rock phosphate

10- Rhizobium + Bacillus megaterium + rock phosphate

After 60 days of planting, plants were uprooted and assayed for number and dry weight of nodules, nitrogenase activity, shoots and roots dry weight. Nitrogen and phosphorus uptake by faba bean plants were determined according to Page et al (1982).

\section{Mycorrhizal colonization ratios}

Representative samples of fresh roots were stained after washing several times according to the procedures of (Phillips and Hayman, 1970). Mycorrhizal colonization ratios of plant roots were determined using the gridline intersect method after staining the root samples (Giovannetti and Mosse, 1980). Data were subjected to analysis of variance according to Snedecor and Cochran (1980).

\section{RESULTS AND DISCUSSION}

Data in Table (2) clearly showed that the used soil in this study contained already indigenous Viscular Arbuscular mycorrhizal (VAM) fungi populations. However, inoculation of soil with rhizobia and mycorrhizae (Glomus sp.) supported higher levels of VAM colonization ratios as compared with the other treatments. Both super- $P$ and rock- $P$ amended soil were more pronounced with super-P amended soil. In this respect, Aryal et al (2003) and Jalaluddin (2005) reported that, dual inoculation of legumes with both rhizobia and VAM fungi maintained high levels of mycorrhizal colonization over than those achieved with rhizobia alone.

In the uninoculated treatments, rock-P fertilized plants exhibited significant increases in VAM colonization ratios when compared with those supplemented with Super-P, irrespective of the nitrogen 
Table 2. Arbuscular-mycorrhizal colonization ratios in faba bean plant roots after 60 days of planting

\begin{tabular}{|l|c|c|c|}
\hline \multirow{2}{*}{ Treatments } & \multicolumn{2}{|c|}{ Phosphate-Source } & \multirow{2}{*}{ Mean } \\
\cline { 2 - 3 } & Super-P & Rock-P & \\
\hline Uninoculated & 16.24 & 30.30 & 23.27 \\
Uninoculated (N-control) & 20.50 & 30.45 & 25.48 \\
Rhizobium & 26.41 & 32.61 & 29.51 \\
Rhizobium + AMF* & 60.63 & 46.00 & 53.32 \\
Rhizobium + BM** & 37.52 & 48.33 & 42.92 \\
\hline \multicolumn{2}{|c|}{3.73} \\
\hline Mean & 32.26 & 37.54 & \\
\hline InD 0.05 Inoc. & \multicolumn{3}{|c}{8.89} \\
P-source & Inoc. X P-source & & \\
\hline
\end{tabular}

* Arbuscular Mycorrhizal Fungus

** Bacillus megaterium var. phosphaticum

dose added. These results are in harmony with those obtained by Nikolaou et al (2002) and Covacevich et al (2006), who concluded that, the percent of mycorrhizal root colonization was higher in insoluble P-form treatments compared to control or to soluble P-form ones.

Irrespective of superiority of rock-P to support VAM colonization ratios in all treatments except in the case of (rhizobia + VAM) treatment which exhibited opposite trend, being 60.63 and $46.00 \%$ for super-P and rock- $\mathrm{P}$, respectively. This could be due to the high stimulation effect of rhizobia and mycorrhizal inoculation which may lead to more activation for $\mathrm{N}_{2}$-fixation that requires more phosphorus to support plant growth. An enhancement of the $\mathrm{N}_{2}$ fixation rates in Rhizobium-inoculated VAM-plants, over that achieved by Rhizobium in nonmycorrhizal plants was previously reported.

Concerning of dual inoculation with Rhizobium and Bacillus, the obtained data showed higher increases in mycorrhizal colonization ratios as compared with noninoculated or only rhizobial inoculated treatments, being most pronounced in the rock-P amended soil.

Data presented in Table (3) presented that $\mathrm{N}_{2}$ -ase activity of root nodules of faba bean inoculated with Rhizobium alone or combined with Amycorrhizae or phosphate solubilizing bacteria gave the highest significant increases when compared to the uninoculated plants. Under rock phosphate treatment, inoculation with Rhizobium, Rhizobium plus VA-mycorrhizae and Rhizobium plus Bacillus megaterium var. phosphaticum stimulated $\mathrm{N}_{2}$-ase activity of root nodules to be 32.00 , 33.55 and $10.93 \square$ mole $\mathrm{C}_{2} \mathrm{H}_{4} /$ plant/hr compared to $11.91,22.45$ and $6.91 \square$ mole $\mathrm{C}_{2} \mathrm{H}_{4} /$ plant/hr under superphosphate fertilizer, respectively. On the contrary, the uninoculated plants gave the lowest nitrogenase activity of 0.26 and $1.06 \square$ mole $\mathrm{C}_{2} \mathrm{H}_{4} /$ plant/hr under both super phosphate and rock phosphate, respectively. On the other hand, combined inoculation of faba bean with Rhizobium and phosphate solubilizing bacteria did not gave any significant effect on $\mathrm{N}_{2}$-activity of faba bean plants compared to those obtained either by Rhizobium or inoculation alone or in combination with VA-mycorrhizae. The increased nodulation and $\mathrm{N}_{2}-$ fixation of legume crops following inoculation with $\mathrm{N}_{2}$-fixing bacteria and phosphate solubilizing microorganizms have been reported by many workers (Algawadi and Guar, 1988; Gupta, 2004).

The obtained results in Table (4) showed clearly that combined inoculation of faba bean with Rhizobium and VA-mycorrhizae gave the highest significant increases in number and dry weight of nodules when compared with the plants inoculated with Rhizobium alone. These increases in number and dry weight of nodules reached to 32.6 and $37.1 \%$, respectively under superphosphate fertilizer, compared to $30 \%$ and $27 \%$ under rock phosphate treatment. These results are in harmony with those obtained by Aryal et al (2003) they found that Rhizobium inoculation influenced positively nodulation of bean plants. On the other hand, combined inoculation of faba bean with Rhizobium and phosphate solubilizing bacteria did not record any significant effect on nodulation of faba bean plants compared to those obtained by Rhizobium inoculation alone. 
Table 3. Effect of inoculation with rhizobia, VA-mycorrhizae and phosphate solubilizing bacteria on $\mathrm{N}_{2}$-ase activity of faba bean plants ( $\square$ mole $\mathrm{C}_{2} \mathrm{H}_{4} /$ plant/hr)

\begin{tabular}{|l|c|c|c|}
\hline \multirow{2}{*}{\multicolumn{1}{|c|}{ Treatments }} & \multicolumn{2}{|c|}{ Phosphate-Source } & \multirow{2}{*}{ Mean } \\
\cline { 2 - 3 } & Super-P & Rock-P & \\
\hline Uninoculated & $1.06 \pm 0.15$ & $0.26 \pm 0.13$ & 0.66 \\
Uninoculated (N-control) & $0.88 \pm 0.10$ & $1.91 \pm 0.87$ & 1.40 \\
Rhizobium & $11.91 \pm 0.74$ & $32.00 \pm 4.30$ & 21.96 \\
Rhizobium + AMF & $22.45 \pm 3.07$ & $33.55 \pm 2.90$ & 28.00 \\
Rhizobium + BM & $6.91 \pm 1.38$ & $10.93 \pm 1.73$ & 8.92 \\
\hline \multicolumn{1}{|c|}{ Mean } & 8.64 & 15.77 & \\
\hline
\end{tabular}

Table 4. Effect of inoculation with rhizobia, VA-mycorrhizae and phosphate solubilizing bacteria on nodulation of faba bean plants

\begin{tabular}{|c|c|c|c|c|c|c|}
\hline \multirow{3}{*}{ Treatments } & \multicolumn{6}{|c|}{ Nodules per plant } \\
\hline & \multicolumn{3}{|c|}{ Number } & \multicolumn{3}{|c|}{ Dry weight (mg) } \\
\hline & Super-P & Rock-P & Mean & Super-P & Rock-P & Mean \\
\hline Uninoculated & 5.0 & 2.7 & 3.8 & 14.67 & 4.67 & 9.67 \\
\hline Uninoculated ( $\mathrm{N}$-control) & 3.7 & 3.0 & 3.3 & 13.33 & 6.00 & 9.67 \\
\hline Rhizobium & 38.7 & 33.3 & 36.0 & 35.00 & 31.67 & 33.33 \\
\hline Rhizobium + AMF & 51.3 & 43.3 & 47.3 & 48.33 & 38.67 & 43.50 \\
\hline Rhizobium + BM & 29.3 & 35.0 & 32.2 & 34.67 & 30.00 & 32.33 \\
\hline Mean & 25.6 & 23.5 & & 29.20 & 22.20 & \\
\hline $\begin{aligned} \text { LSD } 0.05 & \text { Inoc. } \\
& \text { P-source } \\
& \text { Inoc. X P-source }\end{aligned}$ & \multicolumn{3}{|c|}{$\begin{array}{l}2.89 \quad \\
\quad 6.45\end{array}$} & \multicolumn{3}{|c|}{$\begin{array}{l}5.72 \\
1279\end{array}$} \\
\hline
\end{tabular}

Data in Table (5) reveceled that faba bean plants inoculated with Rhizobium alone or combined with VA-mycorrhizae recorded the highest shoot dry weight as compared to the uninoculated plants. Combined inoculation of faba bean with Rhizobiun and VA-mycorrhizae gave increases of $24.2 \%$ and $15 \%$ in shoots dry weight over the uninoculated ones under the application of superphosphate and rock phosphate fertilizers, respectively. With respect to dry weight of roots, Rhizobium inoculation alone or combined with VAmycorrhizae increased significantly dry weight of roots when compared to the uninoculated plants. Combined inoculation with Rhizobium and Amycorrhizae under rock phosphate treatment increased significantly upto $14.9 \%$ over those obtained in plants fertilized with superphosphate. These results are in agreement with those ob- tained by Badr El-Din and Moawad (1988) in which the dual inoculation with both rhizobia and Mycorrhizae induced more significant increases in plant dry weight of lentil and faba bean. On the other hand, there were no significant differences in shoot or root dry weight between combined inoculation with Rhizobium and Bacillus megaterium var. phosphaticum compared to Rhizobium inoculation alone.

Combined inoculation (Table 6) with rhizobia and mycorrhizae significantly increased $\mathrm{N}$-uptake in shoots up to 9.0 and $17.2 \%$ over rhizobial inoculation alone under super- $P$ and rock- $P$, respectively. In addition, rhizobial inoculation increased significantly $\mathrm{N}$-uptake in roots up to 62.7 and $77.5 \%$ over $\mathrm{N}$-control treatments under super-P and rock$P$, respectively. On the other hand, dual inoculation with rhizobia and phosphate solibilizing 
Table 5. Effect of inoculation with rhizobia, VA-mycorrhizae and phosphate solubilizing bacteria on biomass of faba bean plants

\begin{tabular}{|c|c|c|c|c|c|c|}
\hline \multirow{3}{*}{ Treatments } & \multicolumn{6}{|c|}{ Dry wt. (g/plant) } \\
\hline & \multicolumn{3}{|c|}{ Shoot } & \multicolumn{3}{|c|}{ Root } \\
\hline & Super-P & Rock-P & Mean & Super-P & Rock-P & Mean \\
\hline Uninoculated & $6.28 \mathrm{de}$ & $5.93 e$ & 6.10 & 2.85 & 3.29 & 3.07 \\
\hline Uninoculated (N-control) & 7.32ab & $6.83 b c$ & 7.07 & 4.02 & 4.40 & 4.21 \\
\hline Rhizobium & $7.80 \mathrm{a}$ & $6.77 \mathrm{~cd}$ & 7.28 & 4.41 & 4.89 & 4.65 \\
\hline Rhizobium + AMF & $7.62 \mathrm{a}$ & $6.82 \mathrm{bc}$ & 7.22 & 4.62 & 5.31 & 4.97 \\
\hline Rhizobium + BM & $6.89 \mathrm{bc}$ & $6.22 \mathrm{e}$ & 6.55 & 3.39 & 4.19 & 3.79 \\
\hline Mean & 7.18 & 6.52 & & 3.86 & 4.42 & \\
\hline $\begin{aligned} \text { LSD } 0.05 & \text { Inoc. } \\
& \text { P-source } \\
& \text { Inoc. X P-source }\end{aligned}$ & \multicolumn{3}{|c|}{$\begin{array}{l}0.29 \\
0.64\end{array}$} & \multicolumn{3}{|c|}{$\begin{array}{r}0.25 \\
0.55\end{array}$} \\
\hline
\end{tabular}

Table 6. Effect of inoculation with rhizobia, VA-mycorrhizae and phosphate solubilizing bacteria on nitrogen content of faba bean plants

\begin{tabular}{|c|c|c|c|c|c|c|}
\hline \multirow{2}{*}{ Treatments } & \multicolumn{3}{|c|}{ Shoot } & \multicolumn{3}{|c|}{ Root } \\
\hline & Super-P & Rock-P & Mean & Super-P & Rock-P & Mean \\
\hline & \multicolumn{6}{|c|}{ Nitrogen content (mg/plant) } \\
\hline Uninoculated & 187.4 & 162.3 & 174.8 & 29.4 & 30.9 & 30.2 \\
\hline Uninoculated (N-control) & 240.7 & 236.1 & 238.4 & 50.9 & 55.9 & 53.4 \\
\hline Rhizobium & 268.2 & 245.8 & 257.0 & 82.8 & 99.2 & 91.0 \\
\hline Rhizobium + AMF & 292.4 & 288.0 & 275.2 & 71.8 & 91.5 & 81.6 \\
\hline Rhizobium + BM & 208.2 & 199.5 & 203.9 & 45.9 & 88.8 & 67.3 \\
\hline Mean & 239.4 & 220.3 & & 56.15 & 73.26 & \\
\hline $\begin{aligned} \text { LSD } 0.05 & \text { Inoc. } \\
& \text { P-source } \\
& \text { Inoc. X P-source }\end{aligned}$ & \multicolumn{3}{|c|}{14.50} & \multicolumn{3}{|c|}{6.27} \\
\hline
\end{tabular}

bacteria had significant effect on $\mathrm{N}$-uptake in both shoots and roots when compared to uninoculated treatments, received the same dose of $\mathrm{N}$-fertilizer. With respect to $\mathrm{P}$-uptake in faba bean plants (Table 7), combined inoculation with rhizobia and mycorrhizae increased significantly $\mathrm{P}$-uptake in both shoots and roots of faba bean plants under the two sources of phosphorus, when compared to rhizobial inoculation alone. These increases reached to 37.5 and $31.3 \%$ in shoots and roots, under super$\mathrm{P}$, respectively. Under rock-P these increases reached to 38.0 and $47.8 \%$ in the same order. These results are in agreement with those ob- tained by Aryal et al (2003) who indicated that VAM infection showed a significant positive correlation to the shoot phosphate or nitrogen in bean plants.

Also, Badr El-Din and Moawad (1988) found that the dual inoculation with both rhizobia and mycorrhizae induced more significant increases in $\mathrm{N}$ and $\mathrm{P}$ contents of lentil and faba bean. On contrary, combined inoculation with rhizobia and phosphate solubilizing bacteria did not record any significant effect on P-uptake in faba bean plants when compared to the other inoculated treatments. 
Table 7. Effect of inoculation with rhizobia, VA-mycorrhizae and phosphate solubilizing bacteria on phosphorus content of faba bean plants

\begin{tabular}{|c|c|c|c|c|c|c|}
\hline \multirow{2}{*}{ Treatments } & \multicolumn{3}{|c|}{ Shoot } & \multicolumn{3}{|c|}{ Root } \\
\hline & Super-P & Rock-P & Mean & Super-P & Rock-P & Mean \\
\hline & \multicolumn{6}{|c|}{ Phosphorus content (mg/plant) } \\
\hline Uninoculated & 9.64 & 9.05 & 9.3 & 1.30 & 1.21 & 1.3 \\
\hline Uninoculated (N-control) & 37.96 & 33.40 & 35.7 & 2.75 & 2.75 & 2.8 \\
\hline Rhizobium & 48.80 & 50.20 & 49.5 & 3.20 & 2.91 & 3.1 \\
\hline Rhizobium + AMF & 67.10 & 69.3 & 68.3 & 4.20 & 4.30 & 4.2 \\
\hline Rhizobium + BM & 35.51 & 30.14 & 32.8 & 2.11 & 2.00 & 2.0 \\
\hline Mean & 39.8 & 38.4 & & 2.7 & 2.6 & \\
\hline LSD 0.05 Inoc. & \multirow{2}{*}{\multicolumn{3}{|c|}{2.74}} & \multirow{2}{*}{\multicolumn{3}{|c|}{0.29}} \\
\hline P-source & & & & & & \\
\hline Inoc. X P-source & \multicolumn{3}{|c|}{6.14} & \multicolumn{3}{|c|}{0.64} \\
\hline
\end{tabular}

\section{REFERENCES}

Algawadi, A.R. and A.C. Guar (1988). Associative effect of Rhizobium and phosphate solubilizing bacteria on the yield and nutrient uptake of chickpea. Plant and Soil, 105: 241-246.

Aryal, U.K.; H.L. Xu and M. Fujita (2003). Rhizobia and VAM fungal inoculation improve growth and nutrient uptake of bean plants under organic fertilization. Journal of Sustainable Agric., 21(3): 215-220.

Azcon-Aguilar, C. and J.M. Barea (1985). Effect of soil microorganisms on formation of vesicular arbuscular mycorrhizae. Trans. Brit. Mycol. Soc., 83: 222-226.

Badr El-Din, S.M.S. and H. Moawad (1988). Enhancement of nitrogen fixation in lentil, faba bean and soybean by dual inoculation with rhizobia and mycrorrhizae. Plant and Soil, 108: 117-123.

Barea, J.M.; M. Toro; M.O. Orozco; E. Campos and R. Azcon (2002). The application of isotopic $(\mathrm{P}-32$ and $\mathrm{N}-15)$ dilution techniques to evaluate the interactive effect of phosphate-solubilizing rhizobacteria, mycorrhizal fungi and Rhizobium to improve the agronomic efficiency of rock phosphate for legume crops. Nutrient Cycling in Agro-EcoSystems. 63: 35-42.

Batjes, N.H. (1997). A. World data set of derived soil properties by FAO-UNESCO soil unit for global modelling. Soil Use Manage. 13: 9-16.
Bojinova, D.; R. Velkova; I. Grancharov and S. Zhelev (1997). The bioconversion of Tunisian phosphorite using Aspergillus niger. Nutr. Cyc. Agro-Eco-Syst. 47: 227-232.

Covacevich, F.; M.A. Marino and H.E. Echeverria (2006). The phosphorus source determines the arbuscular mycorrhizal potential and the native mycorrhizal colonization of tall fescue and wheatgrass. Eur. J. of Soil Biology. 42: 127-138.

Daniels, B.A. and H.D. Skipper (1982). Methods for recovery and quantitative estimation of propagules from soil. In: Schenck, N.C. (ed), Methods and Principles of Mycorrhizal Research (pp. 2935). AM. Phytopathological Soc., St. Paul, MN, USA.

Earl, C.D. and F.M. Ausubel (1993). The genetic engineering of nitrogen fixation. Nutr. Rev., 41: 16.

Gerke, L. (1992). Phosphate, aluminum and iron in the soil solution of three different soils in relation to varying concentrations of citric acid. Z. Pfl.-Ernahr Bodenkde. ISS: 17-22.

Giovannetti, M. and B. Mosse (1980). An evaluation of techniques for measuring Vesiculararbuscular mycorrhizal infection in roots. New Phytol., 84: 489-500.

Gull, F.Y.; I. Hafeez; M. Saleem and K.A. Malik (2004). Phosphorus uptake and growth promotion of chickpea by co-inoculation of mineral phosphate solubilizing bacteria and a mixed rhizobial culture. Aust. J. Exp. Agric., 44: 623-628. 
Gupta, S.C. (2004). Response of gram (Cicer arietinuny) to types and methods of microbial inoculation. India. J. Agric. Sci., 74: 73-75.

IIImer, P.; A. Barbato and E. Schinner (1995). Solubilization of hardly soluble $\mathrm{AlPO}_{4}$ with $\mathrm{P}$ solubilizing microorganisms. Soil Biol. Biochem., 27: 265-270.

Jackson, M.L. (1973). Soil Chemical Analysis, p. 245. Constable Co. London, Prontice Hall Inc., Englwood Cbiffs, New Jersy.

Jalaluddin, M. (2005). Effect of inoculation with VAM-fungi and Bradyrhizobium on growth and yield of soybean in Sindh. Pakistan J. of Botany. 37: 169-173.

Kang, S.C.; C.G. Ha; T.G.; Lee and D.K. Maheshwari (2002). Solubilization of insoluble inorganic phosphates by a soil fungus fomitopsis sp. PS. 102, Curr. Sci., 82: 439-442.

Kucey, R.M.N.; H.H. Jenzen and M.E. Leggett (1989). Microbially mediated increase in plant available phosphorus. Adv. Agron., 42: 199-228.

Lindsay, W.L.; P.L.G. Viek and S.H. Chien (1989). Phosphate minerals, In: Minerals in Soil Environment. $2^{\text {nd }}$ Ed. pp. 1089-1130. (Eds. Dixon, J.B. and S.B. Weed). Soil Sci. Soc. of Amer., Madison, USA.

Maliha, R.; K. Samina; A. Najma; A. Sadia and L. Farooq (2004). Organic acids production and phosphate solubilization by phosphate solubilizing microorganisms under in vitro conditions. Pak. J. Biol. Sci., 7: 187-196.

Nikolaou, N.; N. Karagiannidis; S. Koundouras and I. Fysarakis (2002). Effects of different $P$ sources in soil on increasing growth and mineral uptake of mycorrhizal Vitis vinifera L. (cv Victoria) vines. J. International Des Sciences De La Vigne Et Du Vin. 36(4):195-204.

Norrish, K. and H. Rosser (1983). Mineral Phosphates in Soil an Australian View Point. pp. 335-361, Academic Press. Metbourne. Csiro/London, U.K./ Australia.

Page, A.I.; R.H. Miller and D.R. Keeney (1982). Methods of Analysis. Part 2, Chemical and Microbiological Properties, Second Edition, Am. Soc. Agron. Inc., Soil Sci. Soc. Am. pp. 595-624.

Peoples, M.B.; D.F. Herridge and J.K. Ladha (1995). Biological Nitrogen Fixation an efficient source of nitrogen for sustainable agriculture. Plant and Soil, 174: 220-225.

Perveen, S.; M.S. Khan and A. Zaidi (2002). Effect of rhizospheric microorganisms on growth and yield of greengram (Phaseolus radiatus). Ind. J. Agric Sci., 72: 421-423.

Phillips, J.M. and D.S. Hayman (1970). Improved procedures for clearing roots and staining parasitic and vesicular-arbuscular mycorrhizal fungi for rapid assessment of infection. Trans. Br. Mycol. Soc., 55: 158-161.

Rajan, S.S.S.; J.H. Watkinson and A.G. Sinclair (1996). Rock Phosphate for direct application to soils. Adv. Agron., 57: 77-159.

Schilling, G.; A. Aransee; A. Deubel; G. Lezovic and S. Ruppel (1998). Phosphorus availability, root exudates and microbial activity in the rhizosphere. Z. Pfl. Ernahr. Bodenkde, 161: 465-478.

Snedecore, G.W. and W.G. Cochran (1980). Statistical Methods, pp. 255-269. Seventh ed., lowa State Univ. Press, Ames, lowa, USA.

Vessey, K.J. (2003). Plant growth promoting rhizobacteria as biofertilizers. Plant and Soil, 255: 571-586.

Vincent, J.M. (1970). A Manual for Practical Study of Root-Nodule Bacteria. IBP Handbook, No. 15, Blackwell Sci., Pub. Oxford, UK.

Zaidi, A. (1999). Synergistic Interactions Of Nitrogen Fixing Microorganisms With Phosphate Mobilizing Microorganisms. p. 150. Ph.D. Thesis, Algath Muslim Univ. Algath.

Zaidi, A.; M.S. Khan and M. Amil (2003). Interactive effect of rhizotrophic microorganisms on yield and nutrient uptake of chickpea (Cicer arietinum L.). Eur. J. Agron., 19: 15-21.

Zaidi, A.; M.S. Khan and A. Amil (2004). Bioassocitive effect of rhizospheric microorganisms on growth yield and nutrient uptake of greengram. J. Plant Nutr., 27: 599-610.

Zapata F. and R.N. Roy (2004). Use of phosphate rocks for sustainable agriculture. In: Fertilizer and Nutrition Bulletin. No. 13. A joint production of the FAO and water development division agency, Food Agriculture Organization of the United $\mathrm{Na}$ tions, Roma. 